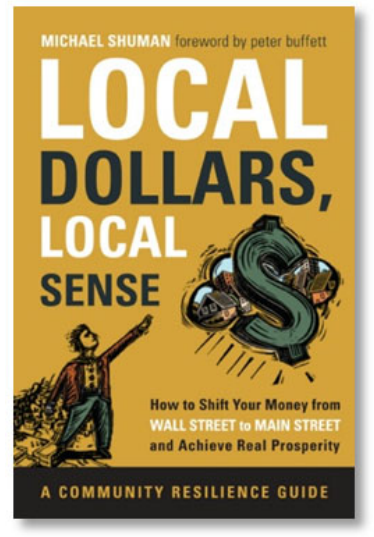

\title{
The end of local?
}

\section{Book Review: Local Dollars, Local Sense: How to Shift Your Money from Wall Street to Main Street and Achieve Real Prosperity, by Michael Shuman}

Review by Ken Meter, Crossroads Resource Center

Shuman, M. (2011). Local dollars, local sense: How to shift your money from Wall Street to Main Street and achieve real prosperity. White River Junction, Vermont: Chelsea Green Publishing.

Published online 19 June 2012

Citation: Meter, K. (2011). The end of local? [review of the book Local Dollars, Local Sense: How to Shift Your Money from Wall Street to Main Street and Achieve Real Prosperity, by M. Shuman]. Journal of Agriculture, Food Systems, and Community Development, 2(3), 211-213. http://dx.doi.org/10.5304/jafscd.2011.023.017

Copyright (C) 2012 by New Leaf Associates, Inc.

$\mathrm{M}$ ichael Shuman and interviewer Kate Poole, in Local Dollars, Local Sense, have combed the continent to uncover solid stories showing how local investment options have been created over the past 35 years. Their close interviews bring considerable practical wisdom.

Especially encouraging, in so doing Shuman has deepened his use of historical precedent as a way of showing that the foundation already has been built for the future he urges us toward. Such an approach requires less showy articulation than in his previous books. To take just a few examples: He documents the pioneering work of Coastal Enterprises, Inc., in Maine, which has directed USD677 million of loans to 2,104 businesses since 1977 (p. 102). He outlines the success of Boston's Wainwright Bank (now Eastern Bank) to offer certificates of deposit (CDs) that channel investment to the coffee trader Equal Exchange, while offering a modest but solid return to investors (p. 86). Shuman also captures the way that La Montanita Co-op in New Mexico uses member capital to lend money to local farmers and food producers (p. 61).

Shuman should also be praised for his formal apology that he had underestimated the potential for cooperatives to promote solid local economies. After considerable tutoring from his colleagues, Shuman has realized that co-ops "are the simplest way most Americans...can make small investments in neighborhood businesses" (p. 45).

Still, Shuman's analysis also shows the limits of "going local" when the national policy infrastructure is not supportive. His prime example of a successful co-op is Organic Valley, the brand name for the CROPP Cooperative in Wisconsin. ${ }^{1}$

\footnotetext{
${ }^{1}$ Disclosure: Organic Valley has occasionally underwritten the costs for this reviewer to make public presentations of his data.
} 
Organic Valley is indeed a stellar example, having grown from eight farmers in a living room in southwest Wisconsin who gathered in 1988 with a determination to reverse the ways the economy extracted wealth from their region, into a USD700 million (see CROPP's 2011 annual report) cooperative of farmer cooperatives, engaging 1,700 farmers, in two decades.

Yet Shuman's own analysis shows that Organic Valley is hardly a classic case of small neighborhood investment. Part of the co-op's success is due to building market power by capturing 10 percent of the organic production in the U.S. and distributing products to most metro areas of the U.S. As Organic Valley has grown, it has attracted an average investment of USD18,500 per investor (p. 55).

This is effective business practice, but hardly exemplifies the "neighborhood" paradigm that Shuman espouses. Organic Valley clearly focuses on consumers with spending power, not its rural neighbors, as its priority market. The co-op has also built much local capacity on a neighborhood basis by constructing local clusters of farmers who trade as locally as possible, under the national umbrella of the co-op. None of this quite fits Shuman's folksy imagery, however.

Rather, he appears to take interest in Organic Valley in large part because it appeals to major investors. For similar reasons, perhaps, he also inexplicably promotes some of the larger cooperatives whose farmer-members feel abandoned by their managers' adoption of impersonal corporate practices.

Shuman might have made his case for very local investment stronger if had he examined at greater depth a study he cites, from the University of Wisconsin Center for Cooperatives (Deller, 2009). Shuman relies on this economic impact report to show the strength of the co-op sector. He develops this argument by citing Organic Valley's sales revenue (which he considers to be USD333 million, a figure he has underestimated by half). Deller states, for example, that approximately 350 co-op groceries across the U.S. earn total sales of USD2.1 billion and have 13,600 employees. The co-op grocery sector has played a key role in many communities since the 1850s, although it ebbs and flows considerably — rising primarily in tough economic times. It has been the paramount vehicle for the emergence of the organic foods market, which has grown in a sustained way more than any other retail channel. This in turn has helped keep mainline supermarkets profitable (Hansen, 2004). ${ }^{2}$ Moreover, without the presence of these co-op groceries, it would have been difficult for Organic Valley to connect to consumers to build its market share.

Such investment is inherently local, and involves small investors indeed. Co-op groceries are small enough, and trusted enough by their members, to respond rapidly as new products are introduced. They have generally engaged earlyadapting shoppers. Once their local purchases are aggregated into a national tally, they represent considerable scale.

In Local Dollars, Local Sense, it is clear that Shuman is coming up to the limits of the word "local" that has characterized his own branding. Indeed, he has been tutored by people in the food movement (who are not credited) to understand that the critical force driving the emergence of many food businesses, especially in an extractive economy, has been to establish a strong sense of community loyalty as a part of doing business.

These are the "triple-bottom-line" businesses that Shuman advocates, but he now grasps new significance in this quest. Shuman concludes, "Even coops that sprawl across the country show many of the characteristics of local businesses" (p. 45).

It is good, at last, to see Shuman acknowledge the networks of people who have long known that forming community connections is more important for transforming our food system than a "locality" measured strictly by miles. This, indeed, is one of the reasons that Equal Exchange has thrived: by building sufficient trust with consumers that they learn about shade-produced, bird-friendly coffee, and demand the product from their suppliers.

\footnotetext{
2 See also the Food Marketing Institute (2005, January 2), which used data from Progressive Grocer to list a 10-year growth rate of 4.8 percent from 1993-2003 for all supermarket items, including nonfood items (www.fmi.org/facts figs/keyfacts/ decade.htm); Natural Foods Merchandiser reported organic sales rising at a steady 16 percent per year, a trend which continues; and also see http://www.crcworks.org/crcnaturalmkts.pdf
} 
Forging this knowledge of production techniques, and a sense of personal engagement, create a kind of "locality" despite the distance. Yet this still must be translated, over the long term, into community wealth and capacity.

As I read the book, I spoke with several investors to get their take on its import. The good news is that the book is being read widely. Most were pleased to read the detailed interviews, while being less persuaded by the specific data Shuman presents. One example is Shuman's misstatement of Organic Valley's revenue, cited above, despite his vow that he has "triple checked" all of the book's numbers.

When Shuman argues that the average return for Wall Street investors during the years 18762010 was merely 2.6 percent per year, he creates a provocative number. Yet in the next sentences he is forced to acknowledge that 2010 is not a great year for making a comparison, given the stock market's vacillation at the end of that decade. Glaringly absent from his account is the recognition that those who invested in Wall Street between 1876 and, say, 1929, were often investing in local firms, not today's global behemoths. This fact undermines his entire comparison.

Ultimately, Shuman settles on a range of from four to five percent as the annual return from a Wall Street portfolio, substantially less than the eight percent promised by many stockbrokers. He makes this calculation by adding the value of dividends to his calculation, removing the adjustment for inflation, and by assuming that an investor keeps his earnings, rather than reinvesting in stocks. Shuman further acknowledges that the actual rate of return depends mightily on when the investment is made and how long it is kept. If the calculations can be trusted, this is an interesting way to draw a comparison that shows that local stocks may offer a comparable rate of return.
Yet as Shuman discusses the fate of "Sam the Saver," a mythical person he conjures to portray potential returns for investors (although of course saving is different than investing), it becomes clear that even under Wall Street, few of us have much opportunity to gain enough for a proper retirement. Local investments may be just as good as corporate, but the average investor starting out today, it would seem from Shuman's analysis, has few hopes of stashing away a reliable nest egg. The difference, if I understand Shuman's argument, is that the average investor once gained a greater return from dividends (p. 3), which are less rewarding now.

Indeed, people may well invest for reasons other than gaining the most money: for example, to build community connection, to become more fully engaged in the production process, and to keep ownership community-minded. Yes, precisely the reasons folks have invested in co-ops during tough times.

For details, see the Chelsea Green Publishing website at http://www.chelseagreen.com/bookstore/item/ local dollars local sense

\section{References}

Coulee Region Organic Produce Pool [CROPP]. (2011). CROPP annual report 2011. Retrieved from http://www.organicvalley.coop/about-us/invest/ stock-prospectus/

Deller, S., Hoyt, A., Hueth, B., \& Sundaram-Stukel, R. (2009, June 19). Research on the economic impact of cooperatives. Madison, Wisconsin: University of Wisconsin Center for Cooperatives. Retrieved from http://reic.uwcc.wisc.edu/

Hansen, N. (Anchor). (2004, December 3). Organic food sales see healthy growth; mainstream food companies promote natural brands [news report]. Retrieved from http://www.msnbc.msn.com/id/6638417/ 